\title{
Parasitic halacarid mites (Acari, Halacaridae): survey on literature
}

\author{
TAPAS CHATTERJEE
}

Near Harimandir Road, Dhanbad 826001, Jharkhand, India, ORCID: 0000-0001-5532-2726

Corresponding author e-mail: drtchatterjee@yahoo.co.in

\begin{abstract}
Keywords Parasitism, Halacaridae, Aquatic Mites, Host
Abstract The article deals with a survey on literature of parasitic halacarid mites. Exact nature of relationship between mites and their invertebrate hosts is unknown for most of these associations, as live observations not found. Some species are assumed to be parasitic.
\end{abstract}

\section{Pasożytniczne wodopójki z rodziny Halacaridae: przegląd literatury}

Słowa kluczowe pasożytnictwo, Halacaridae, wodopójki, gospodarz

Streszczenie Artukuł zawiera przegląd literatury dotyczącej pasożytniczych wodopójek z rodziny Halacaridae. W większości przypadków pasożytniczych wodopójek i ich gospodarzy do dzisiaj nie jest znany dokładny charakter interakcji, ponieważ brak obserwacji osobników żywych. W przypadku części gatunków nie jest jasne nawet czy są pasożytami zwierząt bezkręgowych na których zostały znalezione.

\section{Introduction}

Halacarid mites (Acari, Halacaridae) live in a variety of substrata - within tufts of algae, on large fronds, in and on colonies of sponges, hydrozoans, bryozoans, barnacles, mussels, polychaetes, crustaceans etc. to sediments, flocculent rock crevices and coarse and fine sands (Chatterjee, Sarma 1991; Bartsch, 2006a). Exact nature of relationship between mites and their invertebrate hosts is unknown for most of these associations, as live observation of living material has not been executed. Some species are assumed to be parasitic or commensals or may have been transported accidentally on their hosts (Bartsch, 1987). A brief survey of parasitic halacarid mites was made by Newell (1956) and Bartsch $(1987 ; 1988)$. In present paper a survey on the literature was made to get an updated overview of parasitic halacarid mites. 


\section{Methods}

The present article is prepared based on records published by the end of June 2020. Different author's views about ecological nature of those species were also added.

\section{Results and Discussion}

Halixodes chitonis (Bruker, 1897) was reported based on larvae and protonymphs attached to the gills of mollusc (Mollusca: Polyplacophora) Cryptochonchus porosus (=Acanthochiton porosus) from New Zealand (Brucker, 1897; 1899). Later a subspecies Halixodes chitonis stoutae was reported based on protonymphs in the mantle cavity of tidal gastropods Sigapatella novaezelandiae from New Zealand (Stout, Viets, 1959). Chilton (1883) reported Halixodes truncipes (Chilton, 1883) based on adults (females) collected between tide marks in New Zealand and found not attached to a host. It was assumed that further investigation may prove the Halixodes chitonis chitonis/ Halixodes chitonis stoutae to be juveniles of Halixodes truncipes (Newell, 1956; Bartsch, 1986). Bartsch (1986) reported Halixodes novaezelandiae Bartsch 1986 based on female and deutonymphs collected from crevice systems between gravel and colonies of barnacles and mussels (in Chamaesipho columna and Crassostrea encrustations), Northern Auckland, Newzealand. Two pairs of barbs found at the end of the rostrum in female and deutonymph. The first leg is not stronger; the leg segments are slender and cylindrical; the ventral setae are small and slender; not specialized to catch and hold prey with the first leg. On the other side, the mite is well equipped with the two pairs of barbs at the end of the rostrum to clasp tightly to host tissue (Bartsch, 1986). 'One might speculate that Halixodes feeds rarely, but very substantially. After feeding Halixodes might leave its host and moult, hidden in crevices' - Bartsch (1986).

Astacopsiphagus parasiticus Viets, 1931 was reported as parasite on the fresh water crayfish Euastacus spinifer (Heller) (=Euastacus serratus; =Astacopsis serratus) (Crustacea: Decapoda) from Moran's Creek, Roberts Plateau, MacPherson Range, Queensland National Park in Queensland, Australia, south of Brisbane based on nymphs attached to the gills of the host by the chelicerae (Viets, 1931). Womersley (1943) reported adult male and female which were collected by process of dissecting out the adult inside advanced nymphs found attached to the gill chambers of fresh water crayfish Euastacus sulcatus Clark from Lamington National Park, Queensland, Australia.

Viets (1938) reported an intestinal parasitic halacarid species Enterohalacarus minutipalpis Viets, 1938 found in the gut of a sea urchin, Plesiodiadema indicum at a depth of $430 \mathrm{~m}$ off the west coast of Halmahera Island, Strait of Molucca, Sulu Sea. The species is characterised by reduced palps.

Newell (1956) reported Copidognathus matthewsi Newell, 1956 on the gill chamber of decapods crustacean Parribacus antarcticus based on nymph and adults from Oahu, Hawaii islands, Kaneohe Bay (Tropical Eastern Pacific Ocean).The species apparently lives as a parasite on the gills of the host. The filaments of gills infested by the mite sometimes show necrotic spots apparently due to feeding activities of the mite (Newell, 1956).

Laubier (1960) reported Parahalixodes travei Laubier, 1960 in association with the nemertean Cerebratulus hepaticus from Mediterannean Sea. The species was supposed to be ectoparasite and the enlarged, pointed rostrum and chelicerae are apparently used for piercing the hosts (Laubier, 1960). Newell (1971) reported Parahalixodes chilensis Newell, 1971 based on a protonymph at 
210 m depth off Robinson Crusoe Islands, Jaun Fernandez Islands, Chile. Parhalixodes is believed to be a parasitic genus (Bartsch, 2006).

Genera Halixodes and Parhalixodes have rostra with barbs at the tip; these barbs may enable the mite to stay fixed to the host.

Bartsch (1976) reported Copidognathus stevcici Bartsch, 1976 between the egg mass of crab Maja squinado from eastern North Atlantic and Mediterranean Sea and the species assumed as a parasitic. This species was reported walking on the eggs of Maja squinado collected at Plymoth, England, UK (Green, MacQuitty, 1987). Green \& MacQuitty (1987) also reported that this species found in the 'Michael Collection at the British Museum Natural History' and collection containing lebel 'Portgwarra, spider crab'. This species was also found associated with adult females of the spider crabs Maja brachydactyla and M. squinado under laboratory conditions; mites were observed alive on their host for extended periods and direct evidence of feeding on crab's eggs was also provided (Guerao et al 2011).

Copidognathus gasconi (Gil, Garzón, 1979) (=Velardoacarus gasconi) was reported from gill chamber of a marine crab Peltarion spinulosum (White) (Crustacea: Decapoda) in Uruguayan coast (Gil, Garzón, 1979).

Australacarus inexpectatus Bartsch 1987 described from shallow water in Strait of Magellan, Chile, South Atlantic characterised by the stylet rostrum, dorsoventrally widened palpal segment forming a trough and the slender gnathosoma and assumed to be correlated with life as a parasite (Bartsch, 1987). After discovery of the genus Australacarus, another four species were described under this genus viz. A. pustulatus Bartsch, 1993, A. longipalpus Otto, 2000, A. mesaktanus Otto, 2000, A. zagorskisae Otto, 2000 from Australia among sand and sediments (Bartsch, 1993; Otto, 2000a). The genus is characterised by the palps forming a trough, enclosing the needle-like rostrum and chelicerae and is believed to be a temporary parasite (Bartsch, 2006a). Otto (2000a) commented that feeding has not been observed and a predatory or algivorous lifestyle cannot be ruled out.

Thalassophthirius auster Bartsch, 1988 was reported from sublittoral waters (13-34 m depth) off Staten Island, South Atlantic Ocean. The species is suspected of being parasitic in habit (Bartsch, 1988).

Bartsch (1989) reported Copidognathus sp. from northeast of Lifou, $1420 \mathrm{~m}$ depth and expected it might be ectoparasitic in habit.

Colobocerasides koehleri (Trouessart, 1896) was reported from $1410 \mathrm{~m}$ depth in Gulf of Gascogne, North Sea (Troessart, 1896). Bartsch (1998) redesrbied this species and also reported a new species $C$. auster Bartsch 1998 associated with Polychaeta from Scuthern Atlantic and opined that both species are thought to be temporary ectoparasitic in habit.

Some halacarids were collected from sponges mentioned in early literature (eg. Trouessart, 1914; Viets, 1939; Andre, 1959; Newell, 1984). Majority of them are not only bound on sponges, but also found on other substrates. They are casuals or inhabitants on hydrozoans, bryozoans, algae and sediment contaminating the sponge sample (Bartsch, 1995).

Bartsch (1995) reported a halacarid Halacarellus obsoletus Bartsch, 1995 collected from hexactinellid sponges (Rossella antarctica, $R$. nuda, R. racovitzae, and Scolpnastra joubini) in eastern Weddell Sea, Antarctica. The mites were found within the sponge tissue only, and not found on the surface or in the central cavity of the sponges. Adult mites (males and females) and juveniles were extracted from the hexactinellids. Halacarellus obsoletus is thought to spend all its life within the sponge tissue. The halacarid mites may feed both on sponge tissue and on microfauna within the sponges (Bartsch, 1995). 
Halacarus spongiphilus Kishida, 1927 reported from dictyonine sponges in Sagami Bay, Japan (Kishida, 1927; Abé, 2010). Nature of association, whether mite is a parasite on its sponge host, or just a commensal making use of the sponge for habitation are not clear (Abe, 2010).

Otto (2000b) described a new species Spongihalacarus longiscutus associated with 'sponge weed' (a symbiosis between red algae Ceratodictyon spongiosum and the sponge Halicona cymaeformis) from Great Barrier Reef lagoon in Australia This species is characterised by an almost complete reduction of the palps and possibly a parasitic halacarid (Otto, 2000b).

Caeres-Martinez et al (2000) reported Copidognathus sp. found associated with the mussel Mytilus galloprovincialis from Ensenada, Baja California, NW Mexico, Ensenada Bay.The species was found on the mantle and gills of the host. There was no reported damage to branches or gills resulting from the presence of this halacarid mite. This Copidognathus species was more abundant in the surrounding environment and was scarce inside the mussels. They also commented that this species may be considered as an occasional invader, which seems to be innocuous to their occasional host (Caeres-Martinez et al., 2000). Pepato, Santos, Tiago, (2005) reported two species Copidognathus libiniensis and C. menippensis associated with crabs. Pepato et al. (2005) commented that both mite species have chelicerae with broad movable digits that could be used to pierce the delicate exoskeleton present at the ventral side of the host abdomen of males of Libinia spinosa or the egg membrane of Menippe nodifrons. Pepato et al. (2005) also commented that no direct evidence of feeding on crabs or crab's eggs was found in the study.

Porolohmannella violacea (Kramer, 1879) was found on variety of substrata, sand, flocculent ooze, vascular plants, mosses, algae etc from standing surface waters, swamps, ponds and lakes to high altitude water bodies and was also reported from gill chambers of crayfish Astacus astacus, Astacus leptodactylus (= Potamobius leptodactylus) and Orconectes limosus (Viets, 1927; Bartsch, 2006b; Wiszniewski, 1939; Zawal, 1998). This is an example of accidental or occasional invader of crayfish.

List of halacarid mites associated with decapods crustaceans has been provided in Norman et al (2013): majority of the association (from the list) are probably commensals or occasional invader in nature and only few species like Astacopsiphagus parasiticus, Copidognathus gasconi and C. matthewsi are asumed to be parasitic.

\section{Acknowledgement}

Thanks are due to Dr Hiroshi Abé (College of Bioresource Sciences, Nihon University, Japan) for linguistic help and help to collect some literatue. The author is also thankful to Dr. Almir Pepato (Laboratorio de Sistematics e Evolucao da Acaros Acariformes, Brazil) and Dr. Furkan Durucan (Antalya, Turkey) for their help to collect some literature.

\section{References}

Abé, H. (2010). Redescription of the First Japanese Halacarid Mite, Halacarus spongiphilus (Arachnida: Acari: Halacaridae). Species Diversity, 15, 109-117.

André, M. (1959). Acari I. Contribution a l'étude des halacariens de la Mer Rouge. Mission Robert Ph. Dollfus en Égypte, 26, 93-119.

Bartsch, I. (1976). Copidognathus stevcici n. sp., eine parasitisch lebende Halacaride (Halacaridae, Acari). Thalassia Jugoslavica, 12, 399-404. 
Bartsch, I. (1986). A new species of Halixodes (Halacaridae, Acari) and a review of the New Zealand species. Journal of the Royal Society of New Zealand, 16, 51-56.

Bartsch, I. (1987). Australacarus inexpectatus gen. et spec. nov. (Halacaridae, Acari), mit einer Übersicht über parasitisch lebende Halacariden. Zoologischer Anzeiger, 218, 17-24.

Bartsch, I. (1988). Thalassophthirius auster gen. et spec. nov., a halacarid mite (Acari) suspected of being a parasite. Polar Research, 6, 181-184.

Bartsch, I. (1989). Deep-sea mites (Halacaridae, Acari), from the southwestern Pacific. Cahiers de Biologie Marine, 30, 455-471.

Bartsch, I. (1993). A New Species of Australacarus (Halacaridae, Acari) from Southwestern Australia. Zoologische Jahrbücher, Abteilung für Systematik, Ökologie und Geographie der Tiere, 120, 65-70.

Bartsch, I. (1995). Halacarellus obsoletus n. sp. (Arachnida: Acari: Halacaridae), an associate with Antarctic hexactinellid sponges. Mitteilungen aus dem Zoologischen Museum in Berlin, 71, 121-128.

Bartsch, I. (1998). Colobocerasides koehleri (Trouessart) und C. auster n. sp. (Arachnida: Acari: Halacaridae), Beschreibung der Arten. Mitteilungen aus dem Museum für Naturkunde in Berlin, Zoologische Reihe, 74, 225-232.

Bartsch, I. (2006a). Halacaroidea (Acari): a guide to marine genera. Organisms, Diversity \& Evolution. Electronic Supplement, 6, 1-104.

Bartsch, I. (2006b). The freshwater mite Porolohmannella violacea (Kramer, 1879) (Acari, Halacaridae), description of juveniles and females and notes on development and distribution. Bonner Zoologische Beitrage, 55, 47-59.

Brucker, E.A. (1897). Sur un nouvel Acarien marin. Compte Rendu des Séances de la Société de Biologie, 4, 632-633.

Brucker, E.A. (1899). Halixodes chitonis (Brucker). Bulletin de la Société d'Études Scientifiques d'Angers, 29, 224-226.

Caeceres-Martinez, J., Vasquez-Yeomans, R., Renteria-Guerrero, Y., Curial-Ramirez, Valdez, J.A., Rivas, G. (2000). The marine mites Hyadesia sp. and Copidognathus sp. associated with mussel Mytilus galloprovincialis. Journal of Invertebrate Pathology, 76, 216-221.

Chatterjee, T., Sarma, A.L.N. (1991). Review of Indian Ocean Halacaridae and perspectives of future research. In: V. Gopal, V. Asthana (eds.), Aqatic Sciences in India (pp 189-198). Indian Association of Limnology and Oceanography.

Green, J., MacQuitty, M. (1987). Halacarid Mites. Synopses of the British Fauna, New Series, 36, 178.

Gil, J.I., Garzón, F.M. (1979). Verlardeacarus gasconi n. gen. n. sp. parasitando las branquias de Peltarium spinulosum (White, 1843) (Decapoda Brachyura). Revista de Biologia del Uruguay, 7, 107-116.

Guerao, G., Andree, K.B., Rotllant, G. (2011). Direct evidence of parasitism by Copidognathus stevcici (Acari, Halacaridae) in crabs Maja squinado and M. brachydactyla (Brachyura, Majidae) in the laboratory. Aquaculture, 316, 136-138.

Kishida, K. (1927). Ushio-dani, Ushio-dani-ka [Halacarus spongiphilus, Halacaridae]. P. 978. In: A. Iizuka et al. (eds), Nippon Doubutsu Zukan [Illustrated Encyclopedia of Japanese Animals]. Hokuryukan, Tokyo [in Japanese].

Laubier, L. (1960). Parhalixodes travei n. g., n. sp., un nouvel Halixodinae (Halacariens) ectoparasite de nemerte en Méditerranée occidentale. Acarologia, 2, 541-551.

Newell, I.M. (1956). A parasitic species of Copidognathus (Acari: Halacaridae). Proceedings of the Hawaiian Entomological Society, 16, 122-125.

Newell, I.M. (1971). Halacaridae (Acari) collected during cruise 17 of the R/V Anton Bruun, in the southeastern Pacific Ocean. Anton Bruun Report, 8, 1-58. 
Newell, I.M. (1984). Antarctic Halacaroidea. Antarctic Research Series, 40, 1-284.

Normant, M., Zawal, A., Chatterjee, T., Wojcik, D. (2013). Epibiotic mites associated with the invasive Chinese mitten crab Eriocheir sinensis - new records of Halacaridae from Poland. Oceanologia, 55 (4), 901-915.

Otto, J.C. (2000a). Australacarus (Acari: Halacaridae) from northern Australia, with description of three new species. Records of the Australian Museum, 20, 103-114.

Otto, J.C. (2000b). Spongihalacarus longiscutatus n. gen., n. sp., a marine mite (Acari: Prostigmata: Halacaridae) associated with an alga-sponge symbiosis from the Great Barrier Reef Lagoon in Australia. International Journal of Acarology, 26, 279-283.

Pepato, A.R., Santos, C., Tiago, C.G. (2005). Two new closely related species of Copidognathus (Acari, Halacaridae) associated with crabs. Cahiers de Biologie Marine, 46, 69-79.

Stout, V.M., Viets, K. (1959). Über eine parasitisch lebende Halacaride (Acari) von Neuseeland. Veröffentlichungen des Instituts für Meeresforschung in Bremerhaven, 6, 203-211.

Trouessart, E. (1896). Note préliminaire sur les acariens marins dragués de grandes profondeurs par M. Koehler dans le Golfe de Gascogne (Août - Septembre 1895). Bulletin de la Société Zoologique de France, 21, 102-105.

Trouessart, E. (1914). Acariens. In: Deuxième Expédition Antarctique Française (1908-1910), commandée par le Dr.Jean Charcot. Sciences naturelles, Documents Scientifiques (pp. 1-16). Paris: Masson.

Wiszniewski, J. (1939). Uber die Fauna der Kiemenh"ohle der Flusskrebse. Archiwum Hydrobiologii i Rybactwa, 12, 124-162.

Womersley, H. (1943). On Astacopsiphagus parasiticus Viets 1931 (Acarina-Halacaridae) parasitic in the gill chambers of Euastacus sulcatus Clark M.S. Records of the South Australian Museum, 7, 401-403.

Viets, K. (1927) Mitteilungen über das Vorkomen von Halacariden in der Kiemenhöhle des Flusskrebses. Verhandlungen des Internationalen Verein Limnologie, 3, 460-473.

Viets, K. (1931). Über eine an Krebskiemen parasitierende Halacaride aus Australien. Zoologischer Anzeiger, 96, 115-120.

Viets, K. (1938). Eine merkwürdige, neue, in Tiefsee-Echiniden schmarotzende Halacaridengattung und -Art (Acari). Zeitschrift für Parasitenkunde, 10, 210-216.

Zawal, A. (1998) Water mites (Hydracarina) in the brachial cavity of crayfish Orconectes limosus (Raf. 1817). Acta Hydrobiolgica, 40, 49-54.

Cite as: Chatterjee, T. (2020). (2020). Parasitic halacarid mites (Acari, Halacaridae): survey on literature. Acta Biologica, 27, 5-10. DOI: 10.18276/ab.2020.27-01. 